IRA-International Journal of Education \& Multidisciplinary Studies

ISSN 2455-2526; Vol.13, Issue 02 (November, 2018)

Pg. no. 19-26.

Institute of Research Advances

Institute of

http://research-advances.org/index.php/IJEMS

\title{
Impact of Gendered Cultural Codes on Academic Performance of Female Students at a University in Masvingo, Zimbabwe
}

Dr Lilian Manwa

Senior Lecturer, Great Zimbabwe University. Box 1235. Masvingo, Zimbabwe.

Type of Review: Peer Reviewed.

DOl: http://dx.doi.org.10.21013.jems.v13.n2.p3

How to cite this paper:

Manwa, L. (2018). Impact of Gendered Cultural Codes on Academic Performance of Female Students at a University in Masvingo, Zimbabwe. IRA International Journal of Education and Multidisciplinary Studies (ISSN 2455-2526), 13(2), 19-26.doi: http://dx.doi.org.10.21013.jems.v13.n2.p3

(c) Institute of Research Advances.

This work is licensed under a Creative Commons Attribution-Non Commercial 4.0 International License subject to proper citation to the publication source of the work.

Disclaimer: The scholarly papers as reviewed and published by the Institute of Research Advances (IRA) are the views and opinions of their respective authors and are not the views or opinions of the IRA. The IRA disclaims of any harm or loss caused due to the published content to any party.

Institute of Research Advances is an institutional publisher member of Publishers Inter Linking Association Inc. (PILA-CrossRef), USA. The institute is an institutional signatory to the Budapest Open Access Initiative, Hungary advocating the open access of scientific and scholarly knowledge. The Institute is a registered content provider under Open Access Initiative Protocol for Metadata Harvesting (OAI-PMH).

The journal is indexed \& included in WorldCat Discovery Service (USA), CrossRef Metadata Search (USA), WorldCat (USA), OCLC (USA), Open J-Gate (India), EZB (Germany) Scilit (Switzerland), Airiti (China), Bielefeld Academic Search Engine (BASE) of Bielefeld University, Germany, PKP Index of Simon Fraser University, Canada. 


\section{ABSTRACT}

This study sought to establish the impact of gendered cultural codes on the academic performance of female students at a university in Masvingo, Zimbabwe. The qualitative paradigm involving a case study design was considered the best approach for the current study. A case study design was chosen since the study of culture, gender and academic performance is ethnographic in nature hence the design is most suitable. A sample of thirty female students was conveniently sampled from a population of all part two to four female undergraduates at the institution. In-depth interviews and open-ended questionnaires were the tools which were used to collect data. This study revealed that the academic performance of university female students was greatly influenced by gender codes. The findings indicated that gender codes such as domestic chores and societal beliefs that females are home makers have negative effects on their academic performance. The study also revealed that students advocate emancipation from the bulk of domestic chores. This study recommends that the education system design a syllabus which includes gender issues that will be included in the mainstream curriculum where it can be considered as a subject. This may gradually initiate males in doing domestic chores without destroying the cultural fabric of the society.

Key words:_Gender codes, role socialisation, Culture, Academic performance, Female student

\section{Introduction and Background of the Study}

The academic performance of female students as compared to their male counterparts has taken center stage as of late. Many studies have concentrated on gender differences in the academic performance of males and females in mathematics and science subjects (Eurydice, 2009:5; Saito, 2011:3). In America, Canada and Britain, studies on the differences in performance of males and females in mathematics and sciences have been the focus of a number of scholars for the past twenty five years (Ford, 2002:184). Most researches on academic performance have established that most females are lagging behind most male students. There is a lot of evidence which shows that there are differences in performance between males and females in Zimbabwe and Africa as a whole (Lantagne, 2014; Seshamani \& Shalumba, 2010:4). The differences in academic performance are linked to why most women occupy the less paying jobs, of which, in most cases result in keeping them marginalised. The reason of a gap in academic performance was mainly blamed by many scholars to intelligent quotient (IQ) levels which are different between males and females (Evans, 2003:47). The influence of gendered culutural codes on academic performance of females received minmum attention.

Cultural codes and the dynamics of gender have inspired discussions and debates across a range of disciplines. Most educational debates on gender issues are in most cases linked mainly to the two-tiered terrain of identity and power relations of females. Women in particular are more concerned about equal rights and opportunities and very little attention is given to female academic performance. Watkins (2000:155) states that inequalities in education between men and women extend across a wide range of dimensions including enrolment, completion and academic performance. However, very little is said about the impact of gendered cultural codes on academic performance of females in universities. Granted there are basic behavioural differences between the sexes, but it should be noted that these differences increase with age because children's intellectual biases are being exaggerated and intensified by the gendered culture. It seems a blind eye was turned to the gender roles which burden females more than males.

Gender belief systems are common in all cultures and these include stereotypes of attributes of men and women and attributes towards what is considered appropriate roles and behaviours. Maasik and Solomon (2003:475) define gender code as a culturally constructed belief system that defines and dictates the appropriate roles and behaviour for men and women in society. Ford (2002:19) acknowledges that gender codes exert a powerful grip on each individual and on the social, educational, political and economic systems, in which we live, study and work. Female students are no exception of the pressure gendered cultural codes exert on their lives.

Research has established that gender codes and gender bias, among other determinants of academic performance, have taken their toll on female students as compared to their male counterparts (Cheesman, Simpson, \& Wint, 2006:5; Johnson, 2006:2; OECD, 2011:40; Pedrosa, Dachs, Maia, Andrade \& Carvalho, 2006:8; Watkins, 2000:196). Literature from developed and developing countries has confirmed that females do the bulk of domestic chores and that gendered chores have a powerful grip on them (Evans, 2003:47; Ford, 2002:20; Larson \& Simonis, 2005:4; Rao, 2004:140; United Nations Educational Circular, 2003:143; Williams, Seed \& Mwau, 2002:4). In Zimbabwe, it was established that throughout the education system the female-child lags behind the male-child in both enrolment figures and academic performance due to the gendered cultural codes which are part of the 
Zimbabwean culture (Kasirye, 2009:1; Watkins, 2000:196). It is common knowledge in Zimbabwe that females are the primary caregivers and also do most of the domestic chores at the expense of their education.

Cultural, social and economic factors combine to place young girls and women at a serious disadvantage that starts at home through school and extends into adulthood. The Zimbabwean girl-child and her mother do the bulk of the domestic chores and are overburdened by their gender roles. The facts of gender speak for themselves since it is clear that women and girls have less time to relax as compared to their male counterparts (Manwa, 2014). The Nziramasanga Commission (1999:177) confirmed that many girls and teachers submitted that the girl-child is overloaded with domestic chores when compared with her brother. Rao (2004:140) posits that girls more often are kept at home to help with household chores and housework after school. While their brothers are allowed time for homework, girls actually have less access to school work. The time they spend doing household chores disadvantages them and affects their performance. Access to the library, group discussions and actual reading or study time is greatly reduced to almost half the time of that of their counterparts. When they get that little time to read, they will be so tired that their concentration span is affected.

Rao (2004:140) posits that when girls or women try to combine schooling with home apprenticeship, the choice between work time and study time may lead to family tensions, poor performance, poor lesson attendance, and dropouts. The Nziramasanga Commission (1999:177) mentions that the main challenge of the government of Zimbabwe is to overcome the traditional, stereotyping and other practices that impede equal access to education and achievement of girls and women in education at all levels. It is common knowledge in Zimbabwe that women care for the family in every respect. They plan, prepare and cook meals, wash clothes, clean the home and take care of the sick. The culture of Zimbabwe has a proverb which says "Musha mukadzi" interpreted as, Women are the nest builders. In simple terms, it means women own the home, they are in control of everything and they determine what everyone should eat. Nurturing of children is the mother's business and regardless of sex, all around the world when children cry, they say mummy, the cry seeks the attention of the mother and not of the father. Such gender stereotypes are not only a burden but also inhibit the progress of women.

\section{Statement of the Problem}

The fact that women are lagging behind in academic performance in mathematics and science subjects has become a reality worldwide. The blame for this disparity has for long been placed on genetic differences between men and women. Williams et al. (2002:4) point out that women are two thirds of the world's illiterate and earn one tenth of the world's income and perform two thirds of the world's work. These results are a cause for concern to all governments since women are the poorest and most of them live under the poverty datum line. Hee Chee, Pino and Smith (2005:2) say that women and men are known to differ in their college experiences and face different outcomes. Their academic outcomes have placed most of them in low paying jobs. Establishing the relationship between the fact that women are overburdened by their gender roles and their academic performance is the main thrust of this research. How women cope with the dual task and the extent the gendered cultural codes influence the performance of female university students is the focus of this study. The following are the aims and research objectives which guide in establishing of the impact of gendered cultural codes on performance of female students.

\section{Aim}

The major goal of this study is to find out the types of gendered Zimbabwean cultural codes and how these influence academic performance of female university students.

\section{Objectives:}

The following are the objectives of the study:

1. To discover the impact gendered cultural codes have on the academic performance of female university students.

2. To find out possible solutions to the negative effects of the gendered cultural codes on academic performance of female university students.

\section{Methodology}

The quality of a research study is largely determined by the relationship between the topic, paradigm, research method and the instruments used to collect data. The qualitative paradigm involiving a case study design was sconsidered the best approach when investigating gender issues, culture and the academic performance of female university students. Qualitative studies which deal with human behaviour are best studied qualitatively since it is difficult to quantify human behaviour (Neuman, 2000:122; Neuman, 2006:222; Sidhu, 2003:111). A case study 
examines a social unit as a whole and probes deeply and analyses interaction between factors (Best and Kahn, 1993:93; Neuman, 2006:308). Aggarwal (2008:44) and Nachmias and Nachmias (1995:146) also assert that a case study involves an observation of a single group or event at a single point in time. Hence, a case study was the design best for this research study. A case study involves a relatively small sample which is manageable. The size of the sample maybe small as compared to the size of the population but this was overcome by selecting a sample that included all important variables such as different levels and ethnic groups.

The targeted population for the study was all the four hundred female undergraduate students at the university from part two to four excluding those in part/level one at the university. Part one students were left out since they were new and settling down. The age range of the participants was between nineteen (19) and forty five (45). Very few were in their forties while the majority were between twenty-five (25) and thirty-five (35). Thirty female students in both full time and part-time programmes were conviniently selected. The reason for such a sample was to cater for both the closed and open systems of learning. The sample for the fulltime students consisted of both resident and non-resident students. Neuman (2006: 222) suggests that convinient sampling is appropriate to select unique cases that are especially informative. The nature of the sample requires a careful selection that is purposive in order to cater for the details of the specialised sample. All the students who were willing and forthcoming to participate were part of the sample.

Data collection was mainly done using in-depth interviews which included individual students and focus group discussions. Five students were interviewed and five groups of five students participated in focus group discussions. Boyce and Nealev (2006:2) and Neuman (2000:272) define an in-depth interview as a conversation with a purpose which allows person to person discussion. In-depth interviews were useful in that detailed information about thoughts and behaviours from the participants was captured and also were used to explore new issues in depth. Focus group discussions were used since through discussion a lot of information was gathered in a short period of time. Upadhya and Singh (2010:36) suggest that focus groups are very informative and are best for behaviour investigation. Indviduals may forget some valuable information whereas during discussions participants may remind one another of facts. An interview guide or schedule was developed by the researcher with a list of the questions or issues to be explored during the interviews and focus group discussions.

\section{Procedure}

Data was collected after the researcher has been given permission by the authorities of the university. The process of getting permission was done formally.

\section{Data Presentation and Discussion}

Data were presented and analysed in narrative form and thermatically. Data was presented and analysed around the research questions.

\section{Data Presentation}

The following section is the presentation of data solicited from the thirty participants. Excerpts to verify the findings are also presented.

\section{Influence of Gendered Cultural Codes on Academic Performance}

The current study revealed that the academic performance of university female students is greatly influenced by gender codes. All participants involved in this study indicated that gender codes such as domestic chores and societal beliefs that women belong to the home and are trained for domesticity have a firm grip on the female university students in relation to their academic performance. The findings established that domestic chores such as meal preparation and hosekeeping duties are the major cultural codes that preoccupy the female students and affect their academic performance. The female students' study time is reduced as they perform domestic duties. The following excerpts confirm the findings:

Meal preparation, serving and cleaning of utensils is done on daily basis and this cannot be avoided and these tiresome duties consume most of my study time (P. 1).

Housekeeping chores such as cleaning the home and laundry are so taxing that I fail to do private study due fatigue. Staying in an unclean home is not an option since it is related to poor health which also negatively affects academic performance ( $P .17)$. 
The caring and motherly role is also another gendered role that caused most female students to be absent from lectures. One student indicated that she was torn between university demands and expectations from the family. Caring duties were mentioned by most participants as very cumbersome. The following excerpts confirm these findings:

Routine check-ups of the baby and taking care of children are part of the caring jobs that causes absenteeism. Most lecturers do not understand that not attending lecturers due to such roles is very taxing and stressful (P.30).

Demands of being a wife and a daughter in-law cause mental exhaustion as one will be trying to please everyone. Most family members expect me to do all my duties as a daughter in-law regardless of the weight of being a scholar (P. 7).

\section{Suggestion that Assists in Aliviating the Impact of Gendered Cultural Codes on Academic Performance}

The findings from this study revealed that there is need for finding solutions that may improve the academic performance of university female students. All female students who participated in this study admitted that gendered cultural codes have a negative influence on their academic performance and that there is need to find ways of reducing the burden of gendered cultural codes which hound them. The participants submitted that they have more gender roles that take most of their study time as compared to their male counterparts hence the need to reduce them. Most participants suggested that males should be encouraged to help women as they execute their motherly role. Children are for both parents and they should be taken care of by both parents said one of the students.

The following excerpts substantiate the findings:

I believe that household chores can be shared between males and females without any problem if males are given the chance to do so instead of females to do all the chores without involving them. This will allow females to have more time to do their assignments (21).

Fathers may be involved in caring jobs such as taking care of children in order to reduce the burden on the mothers. My academic performance was compromised during the semester I was nursing due to devided attention (P. 10).

Most participants revealed that policy changes can go a long way in alleviating the burden women have as far as traditional gender roles are concerned. The situation was said by most participants as a cause for concern since all these problems are not considered by most teachers and lecturers when they are marking assignments and tests. Educational policies which are in favour of women can be well achieved in a women friedly political environment. Some participants said that it is known that the courts of law pass verdicts considering all facts and factors surrounding the circumstances but there is no policy with regards to the considerations guiding the assessment of students' work. The following excerpts verify the finding:

Education is one of the tools that can impower us women. Policies which are pro-women may be included and be part of the school curriculum. Female students will perform better if they are in a more female friendly environment (P.3).

Gender issues should be taught in schools from primary level as a subject of gender studies. Sharing of domestic chores should be gradually instilled to the boy child through the subject so that females may also have more chances to study and get good results (P.15).

Affirmative action may start from the lecture room. Marking of assignments, examinations and grading systems should be in favour of female students and lecturers should take into considerations all the gendered differences between male and female students (P.2).

\section{Discussion}

The findings from this study indicated that domestic chores and the motherly role negatively influence the academic performance of female students. The findings relates to Dimbisso's (2009:58) finding that female students have heavy burdens of domestic work that cause unclear minds, increased fatigue, lack of time for assignments and lack 
of commitment to college activities. Similarly, Omenge and Nasango (2010:327) established that there is a close link between female students' participation during lessons and their low academic performance with their involvement in domestic chores. This implies that too much involvement in domestic chores by female university students reduces their participation during lectures and subsequently compromises their academic performance. This finding on domestic chores also confirms Meggitt and Walker's (2007:193) observation that, generally, women do most of the domestic chores compared to their male counterparts. Since feminism advocates equal rights between the sexes in all spheres of life including domestic chores (Ford, 2002:21), the findings of this study contradict this feminist ideal.

Participants in this research who were married and those who had a motherly role were the ones who were torn between a multiple of tedious roles. Most students revealed that it is difficult to cope with role conflict and strain. Manwa (2017) asserts that role conflict is one of the challenges females face when at college. In the same vein, Shirley (1999:102) advocates that the attempt to live in both the public spheres of education and work and private spheres of home and family is particularly complicated and potentially very stressful. Late submission and handing in substandard assignments by female students was mentioned as an indication of the fact that female students work under pressure due to so many roles. Stress was said by most participants as a challenge when it comes to concentrating on studying and during lectures. Good results can only be attained if an individual is able to concentrate fully when attending to school work.

Female student participants who were non-resdent were the ones who affected most since they were operating from home. Resident students who participated in this research were less affected by the motherly role although some had to travel more often in order for them to go and check on the family at home. Larson and Simonis (2005:4) point out that, women are overburdened by their traditional roles, demands from the workplace or school and their own needs. When demands become enormous, the person becomes physically and 'emotionally exhausted. Manwa (2010:4) also asserts that women in Zimbabwe suffer silently to the extent that some of them are stressed to death due to the extra burdens which extend to the extended families. Even with the support of a domestic helper, women still have the primary role or responsibility of handling and organizing most of the domestic chores and child rearing duties. There is a conflict between career, motherhood and marriage (Shirley, 1997:102).

All participants indicated that something is happening in order to emancipate females from the orifice of gender inequality in both developing and developed countries. However, they mentioned that very little is being done about the burden of gender roles which affect females. Wendy (2016) and Benoit (2008:2) suggest that there should be an attempt to bridge the academic performance gap between female and male students. Women academics in the United States of America have traversed difficult terrain in arriving at a central role in higher education, gender equity in education but still much remain to be done on the precipitous road ahead (Aleman \& Renn, 2002: 213). Most participants acknowledged that gender issues have been at the forefront of academic and policy debates for quite some time but the results are still insignificant. Debates of that nature caused the emergency of affirmative action which has been in existence in the United States of America since 1941 and in Zimbabwe at the University of Zimbabwe since in 1993 (Malcom, 1995:17). Aleman and Renn (2002:211) define the term affirmative action as a wide range of voluntary and mandatory activities in the area of education, employment and government contracts. Efforts to close the gender gap using affirmative action have been intensified in both public and private sectors.

Most participants submitted that affirmative action may be implemented at grassroots such as the classroom. They suggested that marking of tests and exercises be done considering that women are preoccupied with gendered codes more than their male counterparts. Aleman and Renn (2002:214) assert that affirmative action in higher education plays a fundamental role in promoting and enhancing the progress and wellbeing of women, citizens and society. Fullinwider (2002:1) affirms that affirmative action refers to positive steps taken to increase the representation of women minorities in areas of education, employment and business. For the participants of this research, education is essential to increase earnings, escape poverty, and enhance self-esteem and to provide adequately for their families. It is a key to development, a major source of women's empowerment and a number of women's diverse range of concerns. Good achievements in academic performance are therefore pivotal in achieving the goal of empowering women.

All participants indicated that women have worked for nearly two centuries to gain access to the public sphere and to improve their quality of life, hence the need to intensify the efforts. Williams et al. (2002:94) state that in the 1980s there has been a growing trend towards seeing women as agents and beneficiaries in all sectors including the 
political arena. Educating women was also considered by most governments as a major way of improving the livelihood of citizens and developing the country (Watkins, 2000). Women education does not merely create one-off benefits, apart from being an important objective in its own right it helps to overcome wider gender-determined inequalities and to create virtuous cycles of human development and poverty reduction (Watkins, 2000:35). Some participants suggested that if women favour the legal equality doctrine, this should be done in a gender-neutral state in which men and women exist as equals. One participant said that special legislation is the solution for the social, economic and political disadvantages women suffer as a result of motherhood and traditional gender roles. Special legislation is the remedy in reducing the disadvantages women endure as a result of motherhood and traditional gender roles (Ford 2002:28).

\section{Conclusions and recommendations}

The findings revealed that the academic performance of all the female students who participated in this study was somehow negatively affected by gendered roles. The effects varied from average to severe where the female student is a mother, a scholar, a wife and the maid. There was evidence from the findings that there was role strain and that most of the female students were operating under stress. The plight of female students needs attention in order to find solutions to close the academic gap.

From the findings of this study, it is recommended that:

- The education system may embrace and include gender issues in the mainstream curriculum where it can be considered as a subject. The subject (gender studies) maybe carefully crafted so that males may be gradually initiated in female dominated gender roles.

- The social fabric of the society should be preserved through monographs which educate both males and females to maintain their dignity but still assisting each other to raise families and to do domestic roles.

- Religious groups may also be encouraged to treat females the same as males and also encourage mutual benefit from both sides.

\section{References}

[1]. Aggarwal, JC. (2008). Essentials of educational pyschology. $2^{\text {nd }}$ Edition New Dehli: Vikas Publishing House Pvt Ltd.

[2]. Aleman, AAM. \& Renn, KA. (2002). Women in higher eduction an encyclopedia. Carlifornia: ABC-CLIO, Inc.

[3]. Arndt, S. (2002). The dynamics of African feminism. Defining and classifying African feminists literature. Eritrea: African World Press.

[4]. Benoit, B. (2008). The effects of parent-teacher communication on student academic performance. Master of Science Thesis. D'youville College.

[5]. Berns, R.M. (2007). Child family, school community: Socialisation and support. ( $7^{\text {th }}$ Edition). Belmont: Thomson Wadsworth.

[6]. Best, JW. \& Kahn, JV. (1993). Research in education. (7 $7^{\text {th }}$ edition). Boston: Allyn and Bacon.

[7]. Bhatt, P. (2007). Educational psychology. India: Authorpress.

[8]. Bogdan, RC. \& Biklen, SK. (1992). Qualitative research in education. An introduction to theory and methods. $\left(2^{\text {nd }}\right.$ Edition) Boston: Allyn and Bacon.

[9]. Cheesman, J, Simpson, N. \& Wint, AG. (2006). Determinants of students performance at university: Reflections from the Caribbeans. UWI, Mana Registry. Campus of the West Indies.

[10]. Dayioglu, M. \& Turut-askik, S. (2007). Gender differences in academic performance in a large Public University in Turkey. Ankara Turkey 53 (255-277) Spring Science + Business Media. http://www.resources.metapress.com/pdf-preview.

[11]. Dorsey, BJ. (1989). Academic women at the University of Zimbabwe: Career prospects, aspirations and family role constraints. Zimbabwe Journal of Educational Research 3: 342-376.

[12]. Eagly, AH. \& Diekmen, AB. (2000). Stereotypes as dynamic constructs: Women and men of the past, present and future. Personality and Social Psychology Bulletin. (26) 1171-1188.

[13]. Eagly, AH., Karau, S. \& Makhinjani, M. (1995) Gender and the effectiveness of leaders: a meta analysis. Psychological Bulletin 117:125-145.

[14]. Eagly, AH., Wood, W. \& Diekmen, AB. (2000). Social role theory of sex differences and similarities. A current appraisal in T.E. Okes and H.M. Trauter (EDs) The Developmental Social Psychology of Gender pp 123-174 Mahwah, N.J. Eribaum.

[15]. Evans, M. (2003). Gender and social theory. U.S.A. Open University Press.

[16]. Ford, LE. (2002). Women in politics: The pursuit of equality. Boston: Haughton Mifflin Company.

[17]. Fullinwider, RK. (2002). Affirmative action in Stanford Encyclopaedia of Philosophy. http://www.plato,stanford.edu/archives/spr2002/entries/affirmative-action.

[18]. Haralambos, M. \& Holborn, M. (2008). Sociology: Themes and perspectives. $7^{\text {th }}$ Edition. London: Unwin and Hyman. 
[19]. Hee Chee, K., Pino, NW. \& Smith, WL. (2005). Gender differences in the academic, ethic achievement. College Student Journal September, 2005.

[20]. Hunter, P. (1998). Development eduction fifteen years on. London: Sage Publications Inc.

[21]. Johnson, JB. \& Reynolds, HT. (2011). Political science and research methods $6^{\text {th }}$ Edition. http://www.sagepub.com/

[22]. Kirchner, VD. (2000). Stereotypes in Perspective: Stereotypical Notion of Women as Inadequate Beings. www.ajol.info/index.php/saje/article/view/44152/27667 (Downloaded July, 2013).

[23]. Lantagne, A. (2014) Gender roles in media https://www.huffingtonpost.com/author/allison-lantagne (Downloaded February, 2018).

[24]. Larson, MH. \& Simonis, GF. (2005). Relief from stress. The Journal of Awake. 86 (3), 3-11.

[25]. Maasik, S. \& Solomon, J. (2003). We've come a long way, maybe: Gender codes in American culture," In Signs of Life in the U.S.A.: Readings on Popular Culture for Writers, New York: St. Martin's, 2003), Pp. 475-483.

[26]. Manwa, L. (2016). The impact of role strain on academic achievement of undergraduate students at a State University in Zimbabwe. PhD. Thesis. University of South Africa (UNISA).

[27]. Manwa, L. (2014\}. Determinants of academic performance of female students at a university in Masvingo Province, Zimbabwe. PhD. Thesis. University of South Africa (UNISA).

[28]. Manwa, L. (2010) The Causes and effects of Stress on Working Women in Masvingo, Zimbabwe. Journal of History and Development. Vol. 1 (2) 36-50.

[29]. Manwa, L., Ndamba, GT. \& Manwa, L. (2010) A gendered dress code and how it influences the choice of dress by women in Zimbabwe. Journal of African Studies and Development Vol. 2(6), pp. 144-149, September 2010 Available online http://www.academicjournlas.org/jasd ISSN - 2141 -2189 (C2010 Academic Journals.

[30]. McKie, R. (2010). The Observer http//observer.guardian.co.uk., Sunday 15 August.

[31]. Meggitt, C. \& Walker, J. (2007). An Introduction to child care and education $2^{\text {nd }}$ Edition. London: Hodder Arnold

[32]. Mohlase, SM. (1997). The careers of women teachers under apartheid. Harare: Sapes Books.

[33]. Neuman, WL. (2006). Qualitative and quantitative approaches. $4^{\text {th }}$ Edition. Boston: Allyn and Bacon.

[34]. Nichamias \& Nichamias (1995). Research methods in the social sciences $5^{\text {th }}$ Edition. New York: St. Martin's Press.

[35]. Nziramasanga Commission of Inquiry. (1999). Report of the presidential commission of inquiry into education and training (In Zimbabwe). Harare: Government Printers.

[36]. Organisation of Economic Corporation and Development. (OECD) (2011). Gender equity: Education, employment and entrepreneurship. EPEC. USA.

[37]. Pearson, J. (2010). Gender and education. http://en.wikipedia,org/wiki/genderandeducation.

[38]. Pedrosa, RHL, Dachs, JNW, Maia, RP, Andrade, CY \& Carvalho, BS. (2006). Education and socioeconomic background of undergraduates and academic performance consequences for affirmative action programs at a Brazilian Research University. Paris: IMHE/OECD.

[39]. Perani, J. and Wolf, N.H. (1999). Cloth, Dress and Art Patronage in Africa._New York: Berg.

[40]. Rao, V. K. (2004). Education System. New Dehli: A.P.H. Publishing Corporation.

[41]. Saito, M. (2011). Gender equality in education looking beyond parity: Trends in gender equality in learning achievement in Southern and Eastern Africa: Exploration of characteristics of educational environment and curriculum areas. Paris: UNESCO. IIEP. www.iiep.unesco.org.

[42]. Sandhya, N. (2004). Research in Value Education. New Dehli: APH. Publishing Corporation.

[43]. Seifert, K. L. and Hoffnung, R.J. (1994). Child and Adolescent development. $3^{\text {rd }}$ Edition. Boston: Houghton Mifflin Company.

[44]. Seshamani, V. and Mwamba, S. (2010). The Gender and Financing Dimensions of Higher Education in Africa. A Case Study in the Zambian Context. Journal of Emerging Trends in Educational Research and Policy Studies. (JETERAPS) 2 (1): 1-8 (ISSN: 2141-6990).

[45]. Sidhu, K.S. (2003). Mothodology of Research in Education. New Dehli: Sterling Publishers Pvt. Ltd.

[46]. Skinner, C. E. (2009). Eductional Psychology $4^{\text {th }}$ Edition. New Dehli: PHI Learning Pvt. Ltd.

[47]. Tassani, P. (2007). Child Care and Education. $4^{\text {th }}$ Edition.U.K. Book Aid International Heinemann.

[48]. The United Nations Children's Fund. (Unicef) (2004). The state of the world's children. girls, education and development. New York: Unic

[49]. Thornham, S. (2000). Feminist theory and cultural studies. Stories of unsettled relations. cultural studies in practice. London: Arnold Press.

[50]. United Nations Educational. (2003). Gender and Education for All. The Leap to Equality. Fance Unesco Publishing.

[51]. Upadhya, B. \& Singh, YK. (2010). Advanced educational psychology. New Dehli: APH. Publishing Corporation.

[52]. Walker, M. (2006) Children's care, learning and development. UK: Nelson Thornes.

[53]. Watkins, K. (2000). The Oxfam Education Report. London: An Oxfam Publication.

[54]. Wendy, C. (2016). Representing women? Leadership roles and women in Canadian broadcast newshttps://www.emeraldinsight.com/author/Cukier\%2C+Wendy

[55]. Wikimedia Foundations. (2011). http://www.wikimediafoundation.org

[56]. Williams, S., Seed, J. \& Mwau, A. (2002). The Oxfam gender training Manual. U.K. Oxfam G.B. 